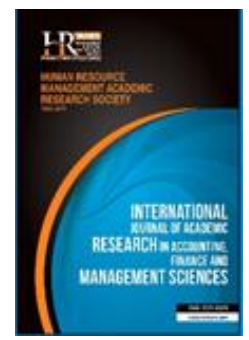

International Journal of Academic Research in Accounting, Finance and Management Sciences

Vol. 8, No.3, July 2018, pp. 95-102

E-ISSN: 2225-8329, P-ISSN: 2308-0337

(c) 2018 HRMARS

www.hrmars.com

To cite this article: Sljabat, F.N. (2018). Entrepreneurial Orientation, Barriers, Business Networks, and Internationalization Readiness: A Conceptual Framework for the SMEs, International Journal of Academic Research in Accounting, Finance and Management Sciences 8 (3): 95-102, http://dx.doi.org/10.6007/JARAFMS/v8-i3/4533 (DOI: 10.6007/JARAFMS/v8-i3/4533)

\title{
Entrepreneurial Orientation, Barriers, Business Networks, and Internationalization Readiness: A Conceptual Framework for the SMEs
}

Ferdi Nazirun SIJABAT

Sekolah Tinggi Ilmu Ekonomi Sabang (STIES), Banda Aceh, Indonesia, E-mail: fnsijabat@gmail.com

\begin{abstract}
In the era of globalization, Small and Medium Enterprises (SMEs) play an important role in advancing Indonesia's economy. This article aims at constructing a conceptual framework for modelling the relationships between entrepreneurial orientation, barriers, business network, and international readiness of the SMEs. This paper is expected to contribute both to theoretical and practical aspects. The proposed conceptual framework for the international readiness of the SMEs covers both quantitative and qualitative aspects of the interactions between entrepreneurial orientation, barriers, business networks, and international readiness of the SMEs in the Indonesian context. As for the practical aspect, this study provides recommendations for government to design proper policy to further promote and enhance the competitiveness of the Indonesian SMEs in the international trading arena.

Key words Entrepreneurial orientation, barriers, business networks, internationalization readiness, SMEs

Received: 20 Aug $2018 \quad$ (c) The Authors 2018

Revised: $\quad 30$ Aug 2018 Published by Human Resource Management Academic Research Society (www.hrmars.com)

Accepted: 10 Sept 2018 This article is published under the Creative Commons Attribution (CC BY 4.0) license. Anyone may Published Online: 18 Sept 2018 reproduce, distribute, translate and create derivative works of this article (for both commercial and noncommercial purposes), subject to full attribution to the original publication and authors. The full terms of this license may be seen at: http://creativecommons.org/licences/by/4.0/legalcode
\end{abstract}

\section{Introduction}

Small and Medium Enterprises (SMEs) play an important role in advancing the Indonesia's economy. In the era of globalization, especially in connection with the implementation of the Association of South East Asian Nation (ASEAN) single market, the SMEs in Indonesia is required to have a competitive edge and capability to penetrate into potential markets across the ASEAN markets. Therefore, the issue of readiness of the internationalization of SMEs has been an important topic that needs to be further investigated both by practitioners and researchers worldwide, including Indonesia. In Indonesian context, studies on the readiness of the SMES to internationalization have a strong relevance if it is associated with positive and negative aspects that may result from the presence of the ASEAN Economic Community since 2015. The AEC as one of pillar of trade liberalization within the ASEAN region has adversely impacted the SMEs in Indonesia that have no competitive advantages compared to the SMEs from other ASEAN economies (Tambunan, 2009; 2012). On the other hand, the SMEs with the competitive edge would enjoy the benefits from the establishment of the AEC due to their readiness and ability to penetrate and internationalize business into other ASEAN markets.

In Indonesia, small enterprise is defined as an independent productive economic activities, executed individually or entities with net assets or annual sales between IDR50 million - IDR500 million or annual sales that reached IDR300 million - IDR2.5 billion. Meanwhile, the medium-sized enterprise is defined as an independent productive economic activities, carried out by individuals or entities with a net worth between IDR500 million - IDR10 billion or annual sales between IDR 2.5 billion - IDR50 billion (Indonesian Act No. 20, 2008). In Indonesia, SMEs in is seen as an economic buffer in times of crisis, where the overall number of 
SMEs in Indonesia is more dominant than the large-scale enterprises. This fact has motivated the government from year to year to provide continues support, both financial and policy adjustment to the SMEs such as channelling small enterprise credit, permanent working capital loans, and the people's business credit (Tambunan, 2012). The government supports have enabled some SMEs to penetrate their businesses into the foreign markets, including the SMEs in the Aceh Province, Indonesia.

Table 1 illustrates the number of SMEs and their businesses with the foreign markets for the year 2014 across 33 provinces in Indonesia. As observed from the table, the number of SMEs that perform marketing activities in the foreign markets was only $4.77 \%$. Of 3,887,130 million SMEs, only 185,599 of them involved businesses in foreign markets. Majority of the SMEs marketed their products and services in the domestic markets within the district/city (3,220,596 SMEs) and outside the district/city (666,534 SMEs) (Indonesian Central Bureau of Statistics, 2014).

Table 1. Domestic and International Markets of SMEs in Indonesia by Provinces, 2014

\begin{tabular}{|c|c|c|c|c|c|c|c|c|c|c|}
\hline \multirow[b]{3}{*}{ No } & \multirow[b]{3}{*}{ Province } & \multirow{3}{*}{$\begin{array}{l}\text { Number } \\
\text { of SMEs }\end{array}$} & \multicolumn{3}{|c|}{ Domestic Market } & \multicolumn{5}{|c|}{ Overseas Market } \\
\hline & & & \multirow{2}{*}{$\begin{array}{l}\text { Inside } \\
\text { Similar } \\
\text { District }\end{array}$} & \multicolumn{2}{|c|}{ Outside } & \multirow[b]{2}{*}{ Overseas } & \multirow[b]{2}{*}{$<25 \%$} & \multirow[b]{2}{*}{$25-49 \%$} & \multirow[b]{2}{*}{$50-79 \%$} & \multirow[b]{2}{*}{$>80 \%$} \\
\hline & & & & $\begin{array}{c}\text { District } \\
\text { within the } \\
\text { Province }\end{array}$ & Province & & & & & \\
\hline 1 & Aceh & 71,031 & 69,535 & 9,274 & 471 & 64 & 71.031 & & & \\
\hline 2 & Sumatera Utara & 86,063 & 80,328 & 21,442 & 2,640 & 155 & 85,991 & 72 & & \\
\hline 3 & Sumatera Barat & 76,520 & 64,563 & 27,337 & 6,903 & 1,243 & 75,516 & 384 & 432 & 188 \\
\hline 4 & Riau & 17,715 & 15,014 & 1,842 & 239 & 50 & 15,701 & 14 & & \\
\hline 5 & Jambi & 27,447 & 26,431 & 4,793 & 666 & & 27,447 & & & \\
\hline 6 & Sumatera Selatan & 64,492 & 54,505 & 17,976 & 5,218 & & 64,492 & & & \\
\hline 7 & Bengkulu & 12,048 & 11,730 & 2,519 & 267 & 16 & 12,048 & & & \\
\hline 8 & Lampung & 103,710 & 98,822 & 20,825 & 2,791 & & 103,710 & & & \\
\hline 9 & Bangka Belitung & 8,267 & 8,033 & 1,070 & 160 & & 8,267 & & & \\
\hline 10 & Kepulauan Riau & 15,399 & 15,238 & 535 & 75 & 61 & 15,363 & 25 & & 11 \\
\hline 11 & DKI Jakarta & 37,858 & 33,500 & 15,279 & 3,636 & 213 & 37,730 & - & 86 & 42 \\
\hline 12 & Jawa Barat & 498,063 & 450,765 & 98,012 & 41,586 & 1,523 & 496,870 & 408 & 351 & 434 \\
\hline 13 & Jawa Tengah & 832,472 & 745,046 & 152,868 & 49,874 & 3,669 & 829,871 & 486 & 319 & 1,796 \\
\hline 14 & DI Yogyakarta & 80,579 & 69,426 & 19,415 & 9,779 & 1,982 & 78,898 & 174 & 281 & 1,226 \\
\hline 15 & Jawa Timur & 648,706 & 594,223 & 137,018 & 36,915 & 210 & 648,496 & 55 & & 155 \\
\hline 16 & Banten & 81,412 & 77,310 & 12,284 & 3,805 & 41 & 81,412 & - & & \\
\hline 17 & Bali & 116,093 & 105,849 & 27,483 & 2,393 & 3,217 & 113,012 & 303 & 1,496 & 1,282 \\
\hline 18 & Nusa Tenggara Barat & 107,231 & 101,250 & 13,097 & 2,318 & 153 & 107,193 & & & 38 \\
\hline 19 & Nusa Tenggara Timur & 112,042 & 109,991 & 11,305 & 430 & 347 & 112,042 & - & & \\
\hline 20 & Kalimantan Barat & 37,412 & 36,174 & 3,558 & 60 & 466 & 37,029 & 90 & 233 & 60 \\
\hline 21 & Kalimantan Tengah & 19,932 & 19,351 & 1,907 & 707 & & 19,932 & & & \\
\hline 22 & Kalimantan Selatan & 70,866 & 64,177 & 15,858 & 9,273 & 1,567 & 70,776 & & & 90 \\
\hline 23 & Kalimantan Timur & 17,721 & 17,665 & 2,301 & 283 & 10 & 17,711 & - & 10 & \\
\hline 24 & Sulawesi Utara & 35,587 & 34,109 & 4,036 & 378 & 28 & 35,587 & - & & \\
\hline 25 & Sulawesi Tengah & 40,296 & 38,713 & 4,664 & 1,281 & 33 & 40,295 & & & \\
\hline 26 & Sulawesi Selatan & 106,419 & 103,163 & 21,776 & 3,851 & 58 & 106,419 & & & \\
\hline 27 & Sulawesi Tenggara & 71,656 & 68,698 & 7,005 & 726 & 39 & 71,517 & 39 & & \\
\hline 28 & Gorontalo & 23,851 & 22,980 & 3,853 & 720 & & 23,851 & - & & \\
\hline 29 & Sulawesi Barat & 29,098 & 27,806 & 1,855 & 1,646 & & 29,098 & - & & \\
\hline 30 & Maluku & 36,640 & 35,804 & 2,891 & 73 & 17 & 36,623 & 17 & & \\
\hline 31 & Maluku Utara & 7,958 & 7,832 & 619 & 89 & & 7,958 & & & \\
\hline 32 & Papua Barat & 2,479 & 2,473 & 91 & 16 & & 2,479 & - & & \\
\hline 33 & Papua & 10,102 & 10,089 & 1,846 & 330 & & 10,102 & & & \\
\hline
\end{tabular}

Source: Indonesian Central Bureau of Statistics (2014). 
As compared to the SMEs in other provinces, the SMEs in Aceh Province are quite unique in terms of their businesses. In this province, the most notable growth of SMEs has been in the beverages sector, especially coffee shop. The increase of coffee shops in the province is quite reasonable due to the increase in the demand of people who willing to spend more with colleagues in the coffee shop, while consuming local coffee menus. In Aceh, the coffee shops two well-known types of coffee shops: (i) common coffee shops - offers Robusta coffee which known as Kupi Ulee Kareng; and (ii) premium coffee shop - provides premium menus of coffee like Arabica Gayo and it's by products like King Gayo, Red Berry, and Pea Berry.

Coffee shops in Aceh can easily be found around the corner of the city. Thus, Aceh has been labelled as the city with 1001 coffee shops. Visiting Aceh would be incomplete without spending time and enjoying coffee in the shops. Around corner of the city, there are many coffee shops. Traditionally, people in Aceh Province gather in the coffee shop for variety of purposes like discussing about social, economic, and political issues and more recently it is also driven by the lifestyle and information and communication technology. Most of the coffee shops in the province are equipped with internet free services.

The entrepreneurial spirit among the coffee businesses in the Aceh Province has been rather strong. It is can be traced back in to the era where many local traders who engaged in doing business with their counterparts from South East Asia, Middle East, America and Europe during 11 century. In the past, some businesses from Aceh have actively traded their agricultural products such as pepper, cloves, camphor, and coffee with traders from western countries.

Previous study on the SMEs internationalization has so far taking place dominantly in the context of developed nations. Only few studies are found to be conducted in the Indonesian context. Mahendrawathi et al. (2014) confirmed that the study on the SME readiness to internationalize their business into the ASEAN market has been limited. Realizing the active involvement of businessman from Aceh in the international trade with the west in the past, thus it is interesting to identify the readiness of the contemporary coffee businesses in the province to penetrate their products and services into international markets and its determinants. This paper, therefore, aims to provide the conceptual framework for the determinants of readiness of coffee shops owners in Aceh Province to internationalize their products. These factors include entrepreneurial orientation, barrier, and business network.

The proposed conceptual framework in this study is hoped to provide a basis for future researches to empirically investigate the determinants of the SMEs readiness to internationalize their products and services. This study also contributes toward modelling the readiness of internationalization of the SMEs in the context of Aceh Province in particular, and in the context of Indonesia at a large.

The rest of the study is structured as follows: Section 2 discusses the previous related literatures on the internationalization readiness, while in Section 3 the conceptual framework based on the past theories and studies are proposed. Section 4 concludes the paper.

\section{Literature Review}

In this section, the previous related studies on the internationalization readiness are reviewed. Determinants of the SMEs readiness for internationalization comprising entrepreneurial orientation, barriers, and business networks are further discussed.

\subsection{SMEs Internationalization}

Studies on the internationalization of SMEs have been conducted for a more than last seven decades. A number of theories and models on this topic have developed such as the Uppsala model introduced by Johanson and Wiedersheim-Paul (1975). This model describes the process of internationalization of the company to foreign markets is done gradually as a consequence of the level of learning made by the company. 18-year later, the network model was developed by Johanson and Mattson (1994) that emphasizes the gradual learning process and the development of knowledge about the market in owned networks. In this model, the juxtaposition was shaped within the dimension of micro (enterprise by enterprise) and macro (companies with networking) (Ruzzier et al., 2006). Fundamentally, the internationalization of SMEs is influenced by the motivation to expand the market and pursue growth (Johanson and Weidesheim-Paul, 1975; Cavusgil, 1995; and Oviatt and McDougall, 1994), the level of 
durability, profitability, economies of scale, supply chain, and the level of business risk (Siriphattasophon and Saiyasopon, 2013; Freiling and Schelhowe, 2014; and David and Cariou, 2014).

However, previous theories on the SMEs internationalization activity are not without criticism. The Uppsala Model, for example, has been criticized by many scholars in the field and even suggested the need to be modified and updated to the current context. Tan et al. (2007) for instance, have complemented the missing aspects in the Uppsala Model by adding the aspect of pre-internationalization stage. They proposed an important proposition in this regard that prior to entering into the internationalization stage; the company is still in the process of pre-internationalization. Likewise, when it started to go in the activities of internationalization, a company has left the pre-internationalization stage.

\subsection{Internationalization Readiness}

Siriphattrasophon and Saiyasopon (2013) studied the readiness of the SMEs in Thailand to internationalize their products and services within the ASEAN economic community (AEC). Researches on the readiness of SMEs are considered highly essential to focus as it highlights the need for the preparation of plans to improve the SMEs' capacity and their worldwide competitiveness. Thus, the SMEs are encouraged constantly evaluating and enhancing their readiness to internationalize their products and services into the foreign markets.

In the Indonesian context, the study on the SMEs' internationalization readiness has been conducted by Mahendrawathi et al. (2014) who found that the SME in the country generally have little knowledge and focus on internationalization, particularly in the context of the implementation of the AEC. Whereas, knowledge of internationalization readiness is considered as essential in order to succeed in the era of the AEC. In their study Mahendrawathi et al. (2014) also documented that the automotive and garment companies in Indonesia possessed lack of understanding on the AEC and generally were unprepared for the establishment of ASEAN single market. For example, in the field of automotive businesses, the business players do not know about the benefits and disadvantages of the AEC for them, although otherwise the garment entrepreneurs already comprehended regarding the benefits and drawbacks of the AEC and commenced to make preparation.

In facing the trade liberalization like the AEC, Tambunan (2012) suggested the government to set priority to the SMEs through capacity building programs to make the SMEs become a business entity that has a global competitiveness and encouraged them to export. Providing the SMEs with the technical assistance, training and regional trade exports facilitation, exports financing schemes, market information, and ease of supply of raw materials would promote the SMEs to move toward a more level of internationalization readiness. In addition, identifying and understanding factors affecting the internationalization readiness for the SMEs would enhance their ability to penetrate into the overseas markets.

\subsection{Factors Affecting the Internationalization Readiness}

In this study, the determinants of internationalization readiness for the SMEs only focuses on entrepreneurial orientation, barriers to internationalization, financial constraints, lack of knowledge, and business network. Understanding these determinants would help the SMEs to prepare themselves to become more competitive at the international arena.

\subsubsection{Entrepreneurial Orientation}

The orientation of the SMEs' owners or managers plays an important role in the successful internationalization of business activities. Hartsfield et al. (2008) stated that the orientation and culture was formed by the owners or managers of the company, and then communicated to all members of the organization. Some researchers argued that the entrepreneurial orientation becomes a determining factor for SMEs to internationalize their businesses (Kumar, 2012; Taylor, 2013).

Previous studies by Koe (2014) and Kusumawardhani et al. (2009) confirmed the significant effect of the entrepreneurial orientation on the business internationalization and its performance. In the dimension of entrepreneurial orientation, it was important for the SMEs to have a working network, which allowing them to obtain resources that have not at their disposal (Kusumawardhani et al., 2009). Likewise, the 
problem of information, if it turned businessmen does not get a lot of information about the intended international market. The Asia-Pacific Economic Cooperation (APEC) in 2007 viewed that the limited access to financial information has been a major obstacle for the SMEs to export their products and services. These findings are consistent with the survey conducted by the Organization for Economic Cooperation and Development (OECD) in 2009. Additionally, Burger et al. (2015) stated that from the various constraints faced by the SMEs there were two of the most crucial problems, namely: (i) the constraint in financial resources; and (ii) limited access to information. Due to these constraints, Burger et al. (2015) found that only less than $3 \%$ of the SMEs market their products and services in the international markets.

\subsubsection{Internationalization Barriers}

Barriers faced by the SMEs in internationalizing their businesses could be categorized into two, namely: (i) internal barrier; and (ii) external barrier (OECD, 2014). Internal barriers are linked to the availability of resources and capabilities of the SMEs to internationalize its activities, while the external barriers refer to the domestic and overseas business environments where the SMEs are undertaking their business activities. In a more detailed, the OECD (2009) identified four barriers to the SMEs with relation to their export activities: (i) lack of capital/financial resources for export; (ii) lack of information for analyzing the foreign market; (3) inability to build relationship with customers abroad; and (4) limitations on managerial time, expertise, and knowledge. Based on these theories, our study only focuses its analysis on financial constraints, lack of knowledge (internal aspect), and business networks (external aspect) as the SMEs barriers.

\subsubsection{Financial Constraints}

Access of the financial resources is another problem faced by the SMEs worldwide to internationalize their products and services (OECD, 2009). It became one of the most crucial issues hinders the SMEs to move toward internationalization (Kumar, 2012). Of the 10 barriers faced by the SMEs in Indonesia, Irjayanti and Aziz (2012) identified access to finance as a major source of problems. In Ghana, Abor et al. (2014) also found that limited financial access of the SMEs to banking has affected their willingness to export activities. In addition, limited financial access of the SMEs to obtain funds both from internal and external sources has also limited their investment spending (Ingolffson, 2011). To overcome these financial constraints, it is a need for policy intervention (Weiland, 2015) to provide more opportunity for the SMEs to obtain cheaper financial sources.

\subsubsection{Lack of Knowledge}

In addition to financial constraints, previous studies also documented that lacks of knowledge adversely affected the SMEs to market their products and services abroad. For example, the lack of knowledge about the market is seen as the cause of the declining performance of the SMEs (Li, 1995). The limited human resources and lack of information was also found by the OECD (2014) as the barriers to internationalization. Knowledge on foreign markets can be gained through market research and business networks (Solberg, 2001). In addition, Siriphattrasophon and Saiyasopon (2013) suggested that the SMEs should be facilitated to gain knowledge and information about how to market and invest abroad through entrepreneurial trainings. Lack of expertise of workers and managers in export activities caused the SMEs to record low productivity level and lack of desire to undertake export activities (Tambunan, 2009; Ahmed et al., 2008). Conversely, the increase in knowledge about overseas markets could generate higher commitment for the SMEs to the internationalization effort (Kalinic and Forza, 2012).

\subsubsection{Business Network}

Next, business network is seen as the crucial factor in the process of internationalization. Networking of business influenced the SMEs' choice of the internationalization markets and how they enter to a foreign market (Chetty and Holm, 2000; Battaglia et al., 2006; Andersson and Helander, 2009), get support and information about targeted foreign markets (Seppo, 2007). Generally, the SMEs from the developed countries like the US and UK recorded higher level of success in building business networks in foreign 
markets that those from the developing counterparts (Khan and Majid, 2012). In short, business network plays an important role for the SMEs to internationalization of the products and services.

\section{Proposed Conceptual Framework for the SMEs Internationalization Readiness}

Based on the above discussion on the theoretical and previous studies, the entrepreneurial orientation, financial constraints, knowledge, and business network are identified to be the potential determinants for readiness of SMEs to internationalize the products and services into the foreign markets. Thus, the following conceptual framework for the SMEs internationalization readiness is proposed.

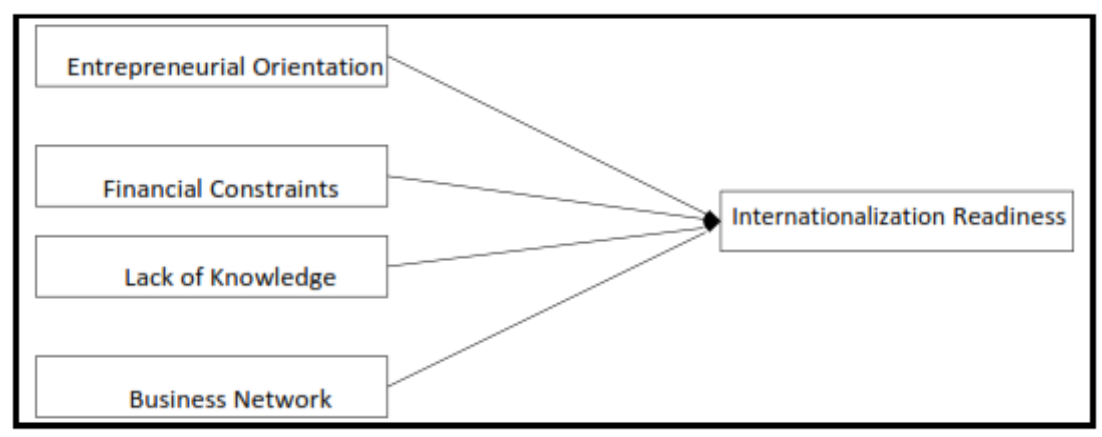

Figure 1. Proposed Conceptual Framework

Based on the above proposed framework, further empirical studies on the SMEs internationalization readiness could test the following proposed hypotheses:

1. Entrepreneurial orientation affects positively the SMEs internationalization readiness;

2. Lack of knowledge affects negatively the SMEs internationalization readiness;

3. Financial constraints affects negatively the SMEs internationalization readiness; and

4. Business network affects positively the SMEs internationalization readiness.

\section{Conclusions}

This study proposed the conceptual framework for modelling the relationships between international readiness of the SMEs and its determinants, namely: entrepreneurial orientation, international and financial barriers, lack of knowledge, and business network. The proposed conceptual framework for the international readiness of the SMEs that covers both quantitative and qualitative aspects was established on the basis of previous theories and empirical evidences. From the theoretical perspective, the proposed conceptual framework are hoped to offer explanations both quantitatively and qualitatively for the interactions between entrepreneurial orientation, barriers, and business network and the Indonesian SMEs readiness to internationalize their business into the foreign markets. As for the practical aspect, this study are hoped to provide recommendations for government to design proper policy and approach to further promote and enhance the competitiveness of the SMEs in Indonesia in the international markets.

\section{References}

1. Abor, J. Y., Agbloyor, E. K., \& Kuipo, R. (2014). Bank finance and export activities of small and medium enterprises. Review of Development Finance, 4(2), 97-103.

2. Ahmed, Z. U., Julian, C. C., \& Jumaat, M. A. (2008). Export barriers and firm internationalisation from an emerging market perspective. Journal of Asia Business Studies, 3(1), 33-41.

3. Andersson, A., \& Helander, A. (2009). The influence of network relationships in the internationalization of SMEs. Thesis. Jonkoping University.

4. Battaglia, L., Corsaro, D., \& Tzannis, A. (2006). The role of networks in the internationalisation of a SME: The case of an Italian company. In the $22^{\text {nd }}$ Industrial Marketing and Purchasing Group Conference, Milano, September.

5. Burger, N., Chazali, C., Gaduh, A., Rothenberg, A. D., Tjandraningsih, I., \& Weilant, S. (2015). Reforming Policies for Small and Medium-Sized Enterprises in Indonesia. Jakarta: TNP2K. 
281.

6. Cavusgil, S. T. (1980). On the internationalization process of the firm. European Research, 6, 273-

7. Chetty, S., \& Holm, D. B. (2000). The Role of Business Networks in the Internationalization of Manufacturing Firms: A Longitudinal Case Study (pp. 205-222). Victoria University of Wellington.

8. David, J. P., \& Cariou, G. (2014). Evaluating the firm's readiness for internationalization: from the design to the application of an international qualification framework. International Journal of Business and Management, 9(7), 1-9.

9. Freiling, J., \& Schelhowe, C. L. (2014). The impact of entrepreneurial orientation on the performance and speed of internationalization. Journal of Entrepreneurship Management and Innovation, 10(4), 169-199.

10. Hartsfield, S., Johansen, D., \& Knight, G. (2017). Entrepreneurial orientation, strategy, and marketing capabilities in the performance of born global firms. International Business: Research, Teaching, and Practice, 2(1), 12-38.

11.Indonesian Act No. 20 (2008). On the Small and Medium Enterprises. Jakarta: Government of Republic of Indonesia.

12.Indonesian Central Bureau of Statistics (2014). Profil Industri Kecil dan Menengah. Jakarta: BPS.

13.Ingolfsson, G. (2011). Financing constraints and internationalization of Danish SMEs: An analysis of financing constraints and its implication on internationalization aspiration of Danish SMEs. Thesis. Aalbor University: Denmark.

14.Irjayanti, M., \& Azis, A. M. (2012). Barrier factors and potential solutions for Indonesian SMEs. Procedia Economics and Finance, 4, 3-12.

15.Johanson, J., \& Mattsson, L. G. (1994). The markets-as-networks tradition in Sweden. In Research Traditions in Marketing (pp. 321-346). Springer, Dordrecht.

16.Johanson, J., \& Wiedersheim-Paul, F. (1975). The internationalization of the firm-four Swedish cases 1. Journal of management studies, 12(3), 305-323.

17.Kalinic, I., \& Forza, C. (2012). Rapid internationalization of traditional SMEs: Between gradualist models and born global. International Business Review, 21(4), 694-707.

18.Khan, B.Z., \& Majid, I. A. (2012). The role of network relationship quality played in the international expansion of SMEs. Interdisciplinary Journal of Research in Business, 2(2), 9-21.

19.Koe, W. (2013). Entrepreneurial orientation and performance of government- linked company. Journal of Entrepreneurship Management and Innovation, 9(3), 221-241.

20.Kumar, D. (2012). Entrepreneurial Orientation and internationalization of SMEs. International Economics \& Finance Journal, 7(2), 1-27.

21.Kusumawardhani, A., McCarthy, G., \& Perera, N. (2009). Framework of entrepreneurial orientation and networking: a study of SMEs performance in a developing country. Proceedings of the Australian and New Zealand Academy of Management Conference (pp. 1-16). Adelaide, Australia: Australian and New Zealand Academy of Management.

22. Mahendrawathi, E. R., Herdiyanti, A., \& Astuti, H. M. (2014). Readiness of Indonesian companies for ASEAN Economic Community (AEC) - Preliminary findings from automotive and garment industry. In Indonesia Proceedings of the 2014 International Conference on Industrial Engineering and Operations Management. Bali, Indonesia.

23.OECD. (2009). Top Barriers and Drivers to SME Internationalisation. Report by the OECD Working Party on SMEs and Entrepreneurship, OECD.

24.OECD. (2014). SMEs internationalisation: Characteristics, barriers and policy options. Symposium on APEC 2015 Priorities, Manila, 8 Desember2014.

25.Oviatt, B.M., \& McDougall, P. P. (1994). Towards a theory of international new ventures. Journal of International Business Studies, 25(1), 45-64.

26. Ruzzier, M., Hisrich, R. D., \& Antoncic, B. (2006). SME internationalization research: past, present, and future. Journal of Small Business and Enterprise Development, 13(4), 476-497.

27.Seppo, M. (2007). The Role of Business Networks in the Internationalization of Estonian Chemical Industry Enterprises. Tartu University Press: Estonia, Tartu. 
28.Siriphattrasophon, S., \& Saiyasopon. (2013). Firm readiness to internationalization of Thai SMEs towards the ASEAN economic community. The 2nd IBSM, International Conference on Business and Management, 2 - 4 October 2013, Chiang Mai - Bangkok.

29.Solberg, C. (2001). Market information and the role of networks in international markets. In Communication Lors de la 17ème Conférence de I'IMP, Oslo, Norvège (pp. 9-11).

30.Tambunan, T. (2009). Development and some constraints of SME in Indonesia. Jakarta: Center for Industry, SME \& Business Competition Studies University of Trisakti.

31.Tambunan, T. (2012). Memberdayakan UMKM dalam meningkatkan kesejahteraan masyarakat menghadapi persaingan global. Prosiding Seminar \& Konferensi Nasional Manajemen Bisnis, 26 Mei, Jakarta, Indonesia.

32.Tan, A., Brewer, P., \& Liesch, P. W. (2007). Before the first export decision: Internationalisation readiness in the pre-export phase. International Business Review, 16(3), 294-309.

33.Taylor, P. (2013). The Effect of entrepreneurial orientation on the internationalization of SMEs in developing countries. African Journal of Business Management, 17, 19.

34.Weiland, S. (2015). Reforming Policies for Small and Medium-Sized Enterprises in Indonesia. Jakarta: TNP2K. 